\title{
Recovery of chitin and chitosan from shrimp waste with microwave technique and versatile application
}

\author{
Recuperação de quitina e quitosana de resíduos \\ de camarão por micro-ondas e aplicação versátil
}

\author{
Vanessa Pimentel Santos ${ }^{1,7}$ (D), Patrícia Maia ${ }^{1,7}$ (D), Nathália de Sá Alencar ${ }^{2,7}$ (D), Laryssa Farias ${ }^{3,7}$ (D), \\ Rosileide Fontenele Silva Andrade ${ }^{4,7}$ (D), Daniele Souza,7 (D), Daylin Rubio Ribaux ${ }^{5,7}$ (D), \\ Luciana de Oliveira Franco ${ }^{6,7}$ (D), Galba Maria Campos-Takaki ${ }^{7 *}$ (D)
}

\begin{abstract}
In this study, chitin and chitosan were extracted from Litopenaeus vannamei waste using chemical and microwave methods. Shrimp waste was cleaned, dried and ground sieved to 16,32 and 60 mesh, and the samples were depigmented, demineralized, and deproteinized. Then, the chitin was submitted to a deacetylation process by $45 \% \mathrm{NaOH}$ solution under microwave irradiation at $600 \mathrm{w}$, for intermittent $15 \mathrm{~min}$ or using 5 pulses of 5 minutes. The study showed that the effectiveness of the particle size of 32 mesh and 6 pulses of 5 min to deacetylation with $92 \%$ of degree and chitosan yield $(52.2 \%)$. The polymer chitosan showed higher antimicrobial activity against to Staphylococcus aureus, Escherichia coli, Salmonella enterica and the yeast Candida sp., respectively. The results indicated the feasibility of the microwave radiation as an attractive method to recover chitin and chitosan from shrimp wastes.
\end{abstract}

KEYWORDS: antibacterial; antifungal; chitosan; radiation; shrimp waste.

\begin{abstract}
RESUMO: Neste estudo, a quitina e a quitosana foram extraídas de resíduos de Litopenaeus vannamei utilizando métodos químicos e do micro-ondas. Os resíduos de camarão foram limpos, secos e peneirados a 16, 32 e 60 mesh, e as amostras foram despigmentadas, desmineralizadas e desproteinizadas. Posteriormente, a quitina foi submetida a processo de desacetilação por solução de $\mathrm{NaOH}$ a $45 \%$ sob irradiaçáo de micro-ondas a $600 \mathrm{w}$, durante $15 \mathrm{~min}$ intermitentes ou utilizando 6 pulsos de $5 \mathrm{~min}$. O estudo mostrou eficácia nas partículas com tamanho de 32 mesh e 6 pulsos de 5 minutos, com $92 \%$ grau de desacetilaçáo e rendimento de quitosana $(52,2 \%)$. A atividade antimicrobiana foi para Staphylococcus aureus, Escherichia coli e Salmonella enterica contra a levedura Candida sp., respectivamente. Os resultados indicaram a viabilidade da radiação de micro-ondas como um método atraente para recuperação de quitina e quitosana a partir de resíduos de camarão.
\end{abstract}

PALAVRAS-CHAVE: antibacteriano; antifúngico; quitosana; radiação; resíduos de camarão.

'Programa de Mestrado em Desenvolvimento de Processos Ambientais, Universidade Católica de Pernambuco - Recife (PE), Brazil

${ }^{2}$ Programa de Doutorado em Biotecnologia, Universidade Federal Rural de Pernambuco - Recife (PE), Brazil

${ }^{3}$ Curso de Graduação em Medicina, Universidade Católica de Pernambuco - Recife (PE), Brazil

${ }^{4}$ Programa Nacional de Pós-Doutorado, Coordenação de Aperfeiçoamento de Pessoal de Nível Superior, Universidade Católica de Pernambuco - Recife (PE), Brazil

${ }^{5}$ Programa de Doutorado em Ciências Biológicas, Universidade Federal de Pernambuco - Recife (PE), Brazil

${ }^{6}$ Departamento de Microbiologia, Universidade Federal Rural de Pernambuco - Recife (PE), Brazil

${ }^{7}$ Núcleo de Pesquisas em Ciências Ambientais e Biotecnologia, Universidade Católica de Pernambuco - Recife (PE), Brazil

*Corresponding author: galba_takaki@yahoo.com.br

Received on: 08/25/2018. Accepted on: 07/30/2019 


\section{INTRODUCTION}

In Brazil, shrimp trade has a strong social-economic impact, and its processing generates large amounts of waste (ALMEIDA et al., 2015). After being peeled and having their heads removed, shrimps lose approximately $47 \%$ of their total weight. The production and disposal of these shells is a significant example of contamination caused by the fishing industry. The shells produce social and environmental problems, due to both their unpleasant odor, and the insects they attract. In addition, this situation may cause damage to human health, because of untreated waste that is discarded (SOUZA et al., 2015).

Otherwise, the release of effluents without previous processing into the environment introduces physical and chemical changes in aquatic ecosystems, considering the large concentrations of nitrogen, phosphorus, organic carbon, suspended solids, and oxygen. Consequently, as a result, the eutrophization process is favored, which impacts negatively the development of animals and plants. In contrast to this situation, reusing them for chitosan polymer production has been a possible solution (COSTA et al., 2015).

Chitin is a natural polymer with a crystalline structure highly organized, insoluble in aqueous solutions, and most of its solvents are organic with low chemical reactivity. Besides that, it is the second most abundant polysaccharide in nature (CASTELEIJN et al., 2018). Similarly, chitosan is a polysaccharide found widely in renewable sources, such as exoskeletons of crustaceans, insects, and fungal cell walls. In this sense, the deacetylation process of chitin by alkaline hydrolysis and subsequent treatment with acidic solutions makes it possible to obtain chitosan formed by 2 -amino- 2 deoxy-D-glucopyranose linked by glycosidic $\beta(1 \rightarrow 4)$. Thechitosan inhibits growth of gram-negative bacteria, is to be attributed to its chemical composition leads to the formation of a polycationic complex between the amino group on chitosan and the outer cell membrane of the bacteria (CREMAR et al., 2018).

Thus, the derivatives of chitin obtained at a degree of deacetylation higher than or equal to $50 \%$ are known as chitosan. The relative proportions of these units generate different structural features, such as the degree of deacetylation and the molecular mass, which are related to the physico-chemical and biological properties of the polymer (CRUZ et al., 2016). When the degree of deacetylation is higher than $70 \%$, chitosan becomes soluble in acidic aqueous solutions and it behaves as a cationic polyelectrolyte suitable for various applications (ABREU et al., 2013).

Additionally, chitosan has been used as a biomaterial, which fits suitable properties, such as biocompatibility, biodegradability, low toxicity, bioactivity and the acceleration of the osteoblasts generation, and tissue healing. Moreover, this polymer has been suggested as a therapeutic agent, because of its antibacterial and antifungal properties (DESBRIÈRES; GUIBAL, 2018).

In this paper, the extraction of chitin from shrimp waste using different sizes of particles with microwave technique and comparing different irradiation times to deacetylaion degree was investigated, followed by the physical-chemical and biological characterizion of chitosan.

\section{MATERIAL AND METHODS}

\section{Shrimp waste}

Chitin was obtained from shrimp residues of the species named as Litopenaeus vannamei, supplied by a commercial marine food establishment located in the city of Vitória de Santo Antão, Pernambuco state, Brazil. Shrimp residues were washed in running water, and, subsequently, with a $2.5 \%$ sodium hypochlorite solution for 48 hours. After that, they were dried in an oven at $80^{\circ} \mathrm{C}$ for 4 hours, and, finally, the material was pulverized in an industrial blender and passed through a 16 , 32 and 60 mesh knit, a modification of a previous methodology (SAMAR et al., 2013).

\section{Microorganisms and culture media}

The bacteria Staphylococcus aureus (Universidade Católica de Pernambuco - UCP: 01576), Escherichia coli (UCP: 01575), Salmonella enterica (UCP: 01505), Klebsiella pneumoniae (UCP: 01574) and yeasts: Candida albicans (UCP: 00993), Candida pelliculosa (UCP: 00994), Candida tropicalis (UCP: 00996) e Candida guilliermondii (UCP: 01592), were kindly supplied by the Culture Collection UCP, Recife, Pernambuco State, Brazil. Culture collection is registered in the World Federation Culture for Collection (WFCC). The bacterial strains were cultured in a medium Nutrient Broth, and the yeasts were grown in medium Sabouraud dextrose liquid.

\section{Chitin extraction}

Chitin extraction was carried out according to SAMAR et al. (2013): 3 different particle sizes of 16, 32, and 60, obtained according to the mesh used, were demineralized with an $\mathrm{HCl}$ solution of $2 \%(\mathrm{v} / \mathrm{v})(10: 1 \mathrm{v} / \mathrm{w})$, and maintained at $30^{\circ} \mathrm{C}$ for 12 hours in order to eliminate biomass. Subsequently, the alkali-insoluble fraction was separated by centrifugation at $4000 \mathrm{~g}$ for 15 minutes. Then, the precipited was washed $4 \mathrm{x}$ with distilled water, and deproteinized to add an $\mathrm{NaOH}$ solution of $4 \%(\mathrm{w} / \mathrm{v})(10: 1 \mathrm{v} / \mathrm{w})$ at $90^{\circ} \mathrm{C}$ for 12 hours. The samples were centrifuged under the same conditions mentioned above, washed four times with distilled water, and dried overnight at $40^{\circ} \mathrm{C}$. The products obtained after 
drying were designated as $\mathrm{C} 16, \mathrm{C} 32$, and $\mathrm{C} 60$, referring to different particle sizes.

\section{Chitosan obtention with microwave technique}

Two methodologies were used for the chitosan deacetylation. In the first, chitin was extracted from the three different mesh sizes of 16,32 , and 60 , which were mixed separatedely with a $45 \%(\mathrm{w} / \mathrm{v}) \mathrm{NaOH}$ solution $(15: 1 \mathrm{v} / \mathrm{w})$. Then, they were placed in a buffered erlenmeyer, into a microwave oven (model Electrolux MEF 33) for irradiation at $600 \mathrm{w}$ for 15 minutes, denominated as methodology A (AL SAGHEER et al., 2009).

The second methodology was modified from the technique described by AL SAGHEER et al. (2009). Samples received the same treatment with $\mathrm{NaOH}$; however, they were irradiated in 6 pulses of 5 minutes at $600 \mathrm{w}$. Between each inter$\mathrm{val}$, they were stirred for homogenization and this was named methodology B.

In both methodologies, samples were filtered and washed with distilled water until neutralization (AL SAGHEER et al., 2009). Afterward, they were washed with acetone (100\%) in the 2:1 ( $/ / \mathrm{w})$ proportion, and placed into the desiccator to dry until constant weight.

\section{Physical-chemical and biological characterization of chitosan}

\section{Elemental analysis}

Chitosan samples of $2 \mathrm{mg}$ were conditioned according to the elemental analyzer Carlo Erba Instruments model EA 1110 to determine carbon, hydrogen, nitrogen and sulfur contents.

\section{Determination of the deacetylation degree}

The deacetylation degree (DD) was verified with the potentiometric titration method, using chitosan samples of $0.05 \mathrm{~g}$, which were dissolved in $10 \mathrm{~mL}$ of $\mathrm{HCl}(0.1 \mathrm{M})$ solution and stirred for 30 minutes (CZECHOWSKA-BISKUP et al., 2012).

When fully dissolved, the $1 \%$ phenolphthalein indicator (two drops) was added in the solution, and then titrated with $0.1 \mathrm{M}$ sodium hydroxide, using a burette until color had changed. The deacetylation chitosan was determined as per Equation 1:

$D D[\%]=2.03 \cdot \frac{V 2-V 1}{m+0.0042 .(V 2-V 1)}$

$\mathrm{m}=$ sample mass;

$\mathrm{V}_{2}, \mathrm{~V}_{1}=$ volumes of $0.1 \mathrm{~mol}$ of $\mathrm{NaOH}$ solution, corresponding to deflection of points;

2.03 = coefficient resulting from the weight of the monomer chitin;
$0.0042=$ coefficient resulting from the difference in molecular weights of chitin and chitosan monomers.

\section{Determination of the minimum inhibitory concentration}

The minimum inhibitory concentration (MIC) was evaluated by microplate serial dilution technique ( 96 holes), according to the supplementary standard M100-S16 of the Manual Clinical and Laboratory Standards Institute (CLSI, 2006). Wells 1 and 2 were filled with $100 \mu \mathrm{L}$ of the Nutrient Broth (NB), or Sabouraud Liquid Dextrose (SDB), followed by 180 $\mu \mathrm{L}$ until the last column. Then, the same volume was placed in the line sequences from $\mathrm{A}$ to $\mathrm{H}$. In column 3, $20 \mu \mathrm{L}$ of the chitosan solution at a $120 \mu \mathrm{g} / \mathrm{mL}$ concentration was added for serial dilution, transferring $100 \mu \mathrm{L}$ from the previous well to the next well, until column 12 . On the other hand, in the first line designed with $\mathrm{A}, 20 \mu \mathrm{L}$ of bacterial or fungal suspension was added to all wells, in columns from 2 to 12 . The microplates were incubated at $37^{\circ} \mathrm{C}$ for 24 hours. After this period, bacterial or fungal growth was conducted, adding $30 \mu \mathrm{L}$ of resazurin developer $(100 \mu \mathrm{g} / \mathrm{mL})$ in each well.

The observation of blue color after two hours indicated the absence of growth; the pink color, the presence of bacterial or fungal growth (PALOMINO et al., 2002).

\section{Statistical analysis}

The data were submitted to analysis of variance, using Statistica 7.0 software. The average results were compared with the Tukey's test with $5 \%$ of probability.

\section{RESULTS AND DISCUSSION}

\section{Yield percentage of chitin and chitosan}

The yield percentage of chitin was calculated from the amount of initial biomass of shrimp exoskeletons (Litopenaeus vannamei). The particle sizes $\mathrm{C} 16$ and $\mathrm{C} 32$ mesh indicated a higher yield, with 79 and $74 \%$, respectively, as shown in Table 1. In this respect, the results obtained by SAMAR et al. (2013) were inferior when they determined chitin yields of 36, 34 and $33 \%$ from 20, 40, and 60 mesh particles, respectively. Palaemon elegans (Ratke 1837), one of crustaceans' species, collected from Cap Midia Gulf, showed 11\% of chitin (APETROAEI et al., 2016). Similarly, ZHANG et al. (2017) obtained a chitin yield of $31.36 \%$ from wastes of Penaeus vannamei. However, studies carried out for HOSSAIN; IQBAL (2014) showed a chitin yield of $17.3 \%$. Thus, such evidence confirmed that shrimp wastes are an abundant source of chitin. 
VILAR JUNIOR et al. (2016) informed yields of 36.6 and $63 \%$ of chitin and chitosan, using exoskeletons of the $L$. vannamei shrimp. In the same study, it was extracted 10.5 and $28.8 \%$ of chitin and chitosan, respectively, from inactivated biomass of Cunninghamella echinulata. These values demonstrated the feasibility of chitin and chitosan extraction from crustacean waste, instead of fungal biomass. ZHANG et al. (2017) achieved a chitosan yield of $13.11 \%$ extracted from Penaeus vannamei shrimp shells. HAJJI et al. (2014), on the other hand, obtained a chitosan yield of $14.9 \%$, using exoskeletons from Penaeus kerathurus. In studies conducted by MOHANASRINIVASAN et al. (2014) chitosan yield achieved $17 \%$ when employing shrimp shells.

Chitosan yields obtained with chitin deacetylation, using microwave technique, are in Table 2. After this process, a higher yield of chitosan from particle sizes of 32 mesh was observed; the particles were acetylated with irradiation for 15 minutes. The reduction in chitosan yield was noticeable when compared to chitin yield, which is related to the removal of the acetyl group through the deacetylation process (SAMAR et al., 2013).

The increase in temperature with the microwave is an alternative to conventional heating protocols. Besides that, evidence suggests that this method improves chemical reactions, and it is considered more efficient (AL SAGHEER et al., 2009).

\section{Elementary analysis of chitin}

The content expressed in percentage of carbon, nitrogen, and hydrogen in chitosan samples (Table 3) was comparable to the values described by BARROS et al. (2006). The authors

Table 1. Chitin yield (\%) obtained from waste shrimp shells with different particle sizes.

\begin{tabular}{|ccc|}
\hline Size (mesh) & Chitin (g) & Chitin (\%) \\
\hline $16^{*}$ & 3.97 & 79.4 \\
\hline $32^{*}$ & 3.70 & 74.0 \\
\hline 60 & 2.11 & 42.2 \\
\hline
\end{tabular}

*Tukey's test: $5 \%$ indicates the difference of the average related to the used mesh.

Table 2. Chitosan samples yield (\%) of different particle sizes obtained from waste shrimp shells with microwave technique.

\begin{tabular}{|cccc|}
\hline Size (mesh) & \multicolumn{1}{c}{ Methodology } & Chitosan (g) & Chitosan (\%) \\
\hline \multirow{2}{*}{16} & A & 2.2 & 44.8 \\
\cline { 2 - 4 } & B & 2.1 & 43.0 \\
\hline \multirow{2}{*}{32} & A & 2.6 & 52.2 \\
\hline \multirow{2}{*}{60} & B & 1.6 & 32.2 \\
\hline & A & 2.2 & 44.4 \\
\hline & B & 2.1 & 42.4 \\
\hline
\end{tabular}

A: continuous irradiation for 15 minutes; B: irradiation in 6 pulses of 5 minutes with agitation between each pulse. totaling 30 minutes of irradiation. determined percentages of $41.09,7.64$, and $6.94 \%$ for carbon, nitrogen and hydrogen, respectively, when chitins extracted from shrimp shells with microwave technique were used. Similarly, SANTOS et al. (2003) characterized three different types of commercial chitosan and found variations in percentage, ranging from 41.2 to $44.5 \%, 7.0$ and $8.5 \%$, and 6.0 and $6.7 \%$ for carbon, nitrogen and hydrogen, respectively.

However, the small percentage of sulfur detected in the samples in this study may be because of the metabisulfite solution aiming to control melanosis in shrimps during their storage, resulting in the presence of sulfur in shrimp shells (ANDRADE et al., 2015).

In general, the chitosan composition determined was approximately $\mathrm{C}_{6} \mathrm{H}_{11} \mathrm{O}_{4} \mathrm{~N}$ for repeated units, when water content is not considered. Chitosan hydration is related to the affinity of this molecule for water. Then, when chitosan is in its solid state, its macromolecules are easily hydrated (FRÁGUAS et al., 2015).

\section{Chitosan deacetylation}

The DD is an important parameter related to the physico-chemical properties of chitosan. In addition, it is

Table 3. Elemental analysis of chitosan samples of different particle sizes obtained from waste shrimp shells with microwave technique.

\begin{tabular}{|c|c|c|c|c|c|}
\hline \multirow{2}{*}{ Size (mesh) } & \multirow{2}{*}{ Methodology } & \multicolumn{4}{|c|}{ Composition (\%) } \\
\hline & & $\mathrm{C}^{1}$ & $\mathrm{H}^{2}$ & $\mathbf{N}^{3}$ & $S^{4}$ \\
\hline \multirow{2}{*}{16} & $A$ & 43.51 & 6.18 & 6.91 & 0.40 \\
\hline & B & 44.28 & 6.54 & 7.12 & 0.50 \\
\hline \multirow{2}{*}{32} & $A$ & 43.59 & 6.40 & 6.82 & 0.47 \\
\hline & B & 44.38 & 6.60 & 6.93 & 0.55 \\
\hline \multirow{2}{*}{60} & $A$ & 44.28 & 6.50 & 6.94 & 0.53 \\
\hline & B & 44.25 & 6.66 & 7.10 & 0.57 \\
\hline
\end{tabular}

${ }^{1}$ Carbon; ${ }^{2}$ hydrogen; ${ }^{3}$ nitrogen; ${ }^{4}$ sulfur; A: continuous irradiation for 15 minutes; B: irradiation in 6 pulses of 5 minutes with agitation between each pulse, totaling 30 minutes of irradiation.

Table 4. Irradiation effects and different particle sizes on the deacetylation degree of chitosan.

\begin{tabular}{ccc} 
Size (mesh) & Methodology & $\begin{array}{c}\text { Deacetylation } \\
\text { degree (\%) }\end{array}$ \\
\hline \multirow{2}{*}{16} & A & 81 \\
\cline { 2 - 3 } 32 & B & 81 \\
& A & 72 \\
\hline \multirow{2}{*}{60} & B $^{*}$ & 92 \\
\hline & A & 78 \\
\hline
\end{tabular}

A: continuous irradiation for 15 minutes; B: irradiation in 6 pulses of 5 minutes with agitation between each pulse, totaling 30 minutes of irradiation; *Tukey's test: $5 \%$ indicates the difference of the average related to the mesh used. 
associated with the distribution of groups acetylated along the polymer chain, being directly related to the solubility of chitosan (FAI et al., 2011).

The DD of chitosan is considered low between 55 and $70 \%$; it is medium between 70 and $85 \%$; and it is high between 85 and $95 \%$. However, between 95 and $100 \%$ it is considered ultra chitosan, although it is difficult to produce the maximum percentage of DD (HE et al., 2016).

Table 4 shows the results of the DD obtained from different particle sizes. Hence, methodology B allowed detecting the higher percentage of deacetylation (92\%), which is associated with the time of reaction between sodium hydroxide and chitin (BENHABILES et al., 2012).

The advantage of the microwave technique is ralated to time decrease, aiming at reducing the average time that is normally between six and eight hours to a few minutes. This represents a suitable alternative to save energy (AL SAGHEER et al., 2009; BENHABILES et al., 2012).

\section{Determination of minimum inhibitory concentration}

The antimicrobial activity of chitosan against several microorganisms, such as bacteria, yeast, and fungi is being verified in recent years (BENHABILES et al., 2012). The results of MIC using chitosan C32, obtained with the microwave technique with 30 minutes of irradiation are shown in Table 5 . The evidence in literature suggests that chitosan with a higher DD tends to have superior antimicrobial properties. Besides the action of these molecules, their physical characteristics are also an important factor, as well as molecular weight and DD (KUMAR et al., 2005).

The MIC for Staphylococcus aureus was $0.46 \mu \mathrm{g} / \mathrm{mL}$, higher than the results described in literature for commercial chitosan with MIC values of 32 (LEE et al., 2014) and $23.4 \mu \mathrm{g} / \mathrm{mL}$ (RAAFAT et al., 2008). In the last case, the authors informed a DD between 75 and $85 \%$.

Table 5. Minimum inhibitory concentration of chitosan obtained from waste shrimp shells through microwave technique against bacteria and yeasts

\begin{tabular}{llc} 
Microorganism & & MIC \\
\hline Staphylococcus aureus & UCP 1576 & $0.46 \mu \mathrm{g} / \mathrm{mL}$ \\
\hline Escherichia coli & UCP 1575 & $30 \mu \mathrm{g} / \mathrm{mL}$ \\
\hline Salmonella enterica & UCP 1505 & $3.75 \mu \mathrm{g} / \mathrm{mL}$ \\
\hline Klebsiella pneumoniae & UCP 1574 & $60 \mu \mathrm{g} / \mathrm{mL}$ \\
\hline Candida albicans & UCP 0993 & $0.23 \mu \mathrm{g} / \mathrm{mL}$ \\
\hline Candida pelliculosa & UCP 0994 & $0.23 \mu \mathrm{g} / \mathrm{mL}$ \\
\hline Candida tropicalis & UCP 0996 & $0.23 \mu \mathrm{g} / \mathrm{mL}$ \\
\hline Candida guilliermondii & UCP 1592 & $30 \mu \mathrm{g} / \mathrm{mL}$ \\
\hline
\end{tabular}

MIC: minimum inhibitory concentration.
The inhibition of growth for Escherichia coli and Salmonella enterica was observed with 30 and $3.75 \mu \mathrm{g} / \mathrm{mL}$ of C32, respectively. Alternatively, O'CALLAGHAN; KERRY (2016) tested commercial chitosan against $E$. coli, and they found the maximum antibacterial action using $0.05 \mu \mathrm{g} / \mathrm{mL}$, whereas ARDILA et al. (2017) reached an MIC of $4 \mu \mathrm{g} / \mathrm{mL}$ against $S$. enterica, employing commercial chitosan.

On the other hand, the growth of Klebsiella pneumoniae was inhibited with $60 \mu \mathrm{g} / \mathrm{mL}$. This result was higher when compared to the findings of MAGESH et al. (2013), who detected inhibition growth with $0.5 \mu \mathrm{g} / \mathrm{mL}$ for $K$. pneumonia.

Nonetheless, Candida albicans, Candida pelliculosa, and Candida tropicalis were inhibited with $0.23 \mu \mathrm{g} / \mathrm{mL}$, which differs slightly from the results found by LEITE et al. (2015), using $0.05 \mu \mathrm{g} / \mathrm{mL}$ of chitosan as an antimicrobial agent against yeasts.

The mechanism of antimicrobial inhibition caused by chitosan is not fully described. However, two theories about the general action of this molecule have been discussed. By one side, it have been suggested that owing to the polycationic nature of chitosan electrostatic forces are stablished between its protonated amino group $\left(\mathrm{NH}_{2}\right)$ and residues on the cell surfaces of microorganisms. By other side, the second mechanism put forward the blocking of the RNA transcription as the main action that irreversibly effects on microbial growth DNA, according to BENTO et al. (2009).

The studies with chitosan obtained from waste shrimp cells showed MIC values in a range of 0.23 to $60 \mu \mathrm{g} / \mathrm{mL}$ against gram-positive and gram-negative bacteria, as well as to yeasts (Table 5). The results obtained in this study show the chitosan from waste shrimp cells particle 32 meshes as suitable for production of quality chitosan. The chitosan antimicrobial activity suggest that biopolymer could become a promising compound for controlling Staphylococcus aureus, Salmonella enterica, Klebsiella pneumoniae, Escherichia coli and yeasts.

\section{CONCLUSION}

Results indicated that microwave irradiation may be used as a simple, efficient, and rapid heating method for chitosan extraction. Shrimp residues were an excellent source of chitin. Consequently, higher yields of chitosan were obtained. The maximum $\mathrm{DD}$ was obtained from chitin samples irradiated from six pulses, and with a particle size of 32 mesh according to those used. The inhibitory effects differed depending on the microorganism tested, with a higher antimicrobial activity against Candida sp. Therefore, due to the versatile nature of chitosan as a biocompatible, biodegradable and non-toxic compound, this biopolymer confirms its promising future in several areas within the industry. 


\section{ACKNOWLEDGMENTS}

Research was supported by Conselho Nacional de Desenvolvimento Científico e Tecnológico (CNPq; Process No. 311373/2014-3) and Fundação de Amparo à
Ciência e Tecnologia do Estado de Pernambuco, (FACEPE; Process No. APQ-0291-2.12/15), and the authors would like to express their especial regards to S.H. Almeida, who provided technician support in the laboratories of NPCIAMB-UNICAP.

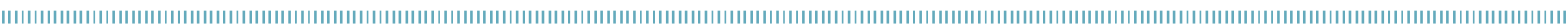
REFERENCES

ABREU, F.O.M.S.; CAVALCANTE, L.G.; DOUDEMENT, P.V.; CASTRO, A.M.; NASCIMENTO, A.P.D.; MATOS, J.E.X. Propriedades e características da quitosana obtida a partir do exoesqueleto de caranguejo-uça utilizando radiação de microondas. Polímeros, São Carlos, v.23, n.5, p.630-635, 2013. http://dx.doi. org/10.4322/polimeros.2013.042

AL SAGHEER, F.A.; AL-SUGHAYER, M.A.; MUSLIM, S.; ELSABEE, M.Z. Extraction and characterization of chitin and chitosan from marine sources in Arabian Gulf. Carbohydrate Polymers, v.77, n.2, p.410419, 2009. https://doi.org/10.1016/j.carbpol.2009.01.032

ALMEIDA, L.; RODRIGUES, W.L.; AGUIAR, N.V.; SILVA, R.S.; MOREIRA, C.K.P. Extração de quitina, síntese e caracterização de quitosana obtida através de resíduos de camarão (Macrobrachium amazonicum). Blucher Chemical Engineering Proceedings, v.1, n.3, p. 2272-2278, 2015. http://dx.doi.org/10.5151/ chemeng-cobeqic2015-477-34107-262119

ANDRADE, L.T.D.; ARAÚJO, N.G.; VENTURA, A.P.M.; LIRA, A.D.L.; MAGNANI, M.; CAVALHEIRO, J.M.D.O. Standardization of sodium metabisulfite solution concentrations and immersion time for farmed shrimp Litopenaeus vannamei. Ciência Rural, v.45, n.3, p.499-504, 2015. http://dx.doi.org/10.1590/0103-8478cr20140806

APETRoAel, M.R.; APETROAEI, G.M.; ATODIRESEI, D.; SCHRODER, V. Extraction and characterization of chitosan from local marine resources. "Mircea cel Batran" Naval Academy Scientific Bulletin, v.19, n.1, p.9-12, 2016 . https://doi. org/10.21279/1454-864X-16-I1-001

ARDILA, N.; DAIGLE, F.; HEUZEY, M.C.; AJJI, A. Effect of chitosan physical form on its antibacterial activity against pathogenic bacteria. Journal of Food Science, v.82, n.3, p.679-686, 2017. https://doi.org/10.1111/1750-3841.13635

BARROS, F.C.F.; CAVALCANTE, R.M.; CARVALHO, T.V.; DIAS, F.S.; QUEIROZ, D.C.; VASCONCELOS, L.C.G. Produção e caracterização de esfera de quitosana modificada quimicamente. Revista Iberoamericana de Polímeros, v.7, n.4, p.232-246, 2006.

BENHABILES, M.S.; SALAH, R.; LOUNICI, H.; DROUICHE, N.; GOOSEN, M.F.; MAMERI, N. Antibacterial activity of chitin, chitosan and its oligomers prepared from shrimp shell waste. Food Hydrocolloids, v.29, n.1, p.48-56, 2012 . https://doi.org/10.1016/j. foodhyd.2012.02.013

BENTO, R.A.; STAMFORD, T.L.; CAMPOS-TAKAKI, G.M.; STAMFORD, T.; SOUZA, E.L.D. Potential of chitosan from Mucor rouxxi UCPO64 as alternative natural compound to inhibit Listeria monocytogenes.
Brazilian Journal of Microbiology, v.40, n.3, p.583-589, 2009. http://dx.doi.org/10.1590/S1517-83822009000300022

CASTELEIJN, M.G.; RICHARDSON, D.; PARKKILA, P.; GRANQVIST, N.; URTTI, A.; VIITALA, T. Spin coated chitin films for biosensors and its analysis are dependent on chitin-surface interactions. Colloids and Surfaces A: Physicochemical and Engineering Aspects, n.539, p.261-272, 2018. https://doi. org/10.1016/j.colsurfa.2017.12.036

CLINICAL AND LABORATORY STANDARDS INSTITUTE (CLSI). Manual Clinical and Laboratory Standards Institute. Methods for dilution antimicrobial susceptibility tests for bacteria that grow aerobically: approved standards- 6th ed. Performance standards for antimicrobial susceptibility testing. Sixteenth informational supplement M100-S16 (tab 2J). Wayne, PA: Clinical and Laboratory Standards Institute, 2006.

COSTA, W.M.; LAVANDER, H.D.; GÁLVEZ, A.O.; ARANA, L.A.V. Estudo comparativo de dois reatores híbridos no tratamento de efluentes heterotróficos de cultivo de camarão marinho. Revista Brasileira de Engenharia de Pesca, v.7, n.2, p.77-85, 2015. https://doi.org/10.18817/repesca.v7i2.1102

CREMAR, L.; GUTIERREZ, J.; MARTINEZ, J.; MATERON, L.; GILKERSON, R.; XU, F.; LOZANO, K. Development of antimicrobial chitosan based nanofiber dressings for wound healing applications. Nanomedicine Journal, v.5, n.1, p.6-14, 2018. https://doi.org/10.22038/NMJ.2018.05.002

CRUZ, J.B.; CATÃO, C.D.S.; BARBOSA, R.C.; FOOK, M.V.L. Synthesis and characterization of chitosan scaffolds with antineoplastic agent. Matéria (Rio J.), Rio de Janeiro, v.21, n. 1, p.129-140, 2016. http://dx.doi.org/10.1590/S1517-707620160001.0012

CZECHOWSKA-BISKUP, R.; JAROSIŃSKA, D.; ROKITA, B.; ULAŃSKI, P.; ROSIAK, J.M. Determination of degree of deacetylation of chitosan-comparison of methods. Progress on Chemistry and Application of Chitin and its Derivatives, n. 17, p.5-20, 2012.

DESBRIĖRES, J.; GUIBAL, E. Chitosan for wastewater treatment. Polymer International, v.67, n.1, p.7-14, 2018. https://doi.org/10.1002/pi.5464

FAI, A.E.C.; STAMFORD, T.; STAMFORD-ARNAUD, T.M.; SANTACRUZ, P.D.; SILVA, M.C.; CAMPOS-TAKAKI, G.M.; STAMFORD, T.L. Physico-chemical characteristics and functional properties of chitin and chitosan produced by Mucor circinelloides using yam bean as substrate. Molecules, v.18, n.8, p.7143-7154, 2011. https://doi.org/10.3390/molecules 16087143 
FRÁGUAS, R.; ROCHA, D.; REZENDE QUEIROZ, E.; ABREU, C.M.P.; SOUSA, R.V.; OLIVEIRA JÚNIOR, E.N. Caracterização química e efeito cicatrizante de quitosana, com baixos valores de massa molar e grau de acetilação, em lesões cutâneas. Polímeros, v.25, n.2, p.205-211,2015. http://dx.doi.org/10.1590/0104-1428.1778

HAJJI, S.; YOUNES, I.; GHORBEL-BELLAAJ, O.; HAJJI, R.; RINAUDO, M.; NASRI, M.; JELLOULI, K. Structural differences between chitin and chitosan extracted from three different marine sources. International Journal of Biological Macromolecules, n.65, p.298306, 2014. https://doi.org/10.1016/j.ijbiomac.2014.01.045

HE, X.; LI, K.; XING, R.; LIU, S.; HU, L.; LI, P. The production of fully deacetylated chitosan by compression method. The Egyptian Journal of Aquatic Research, v.42, n. 1, p.75-81, 2016. https:// doi.org/10.1016/j.ejar.2015.09.003

HOSSAIN, M.S.; IQBAL, A. Production and characterization of chitosan from shrimp waste. Journal of the Bangladesh Agricultural University, v.12, n.1, p.153-160, 2014. https://doi.org/10.3329/ jbau.v12i 1.21405

KUMAR, A.B.V.; VARADARAJ, M.C.; GOWDA, L.R.; THARANATHAN, R.N. Characterization of chito-oligosaccharides prepared by chitosanolysis with the aid of papain and Pronase, and their bactericidal action against Bacillus cereus and Escherichia coli. Biochemical Journal, v.391, n.2, p.167-175, 2005. https://doi. org/10.1042/BJ20050093

LEE, D.S.; EOM, S.H.; KIM, Y.M.; KIM, H.S.; YIM, M.J.; LEE, S.H.; KIM, D.H.; JE, J.Y. Antibacterial and synergic effects of gallic acid-graftedchitosan with $\beta$-lactams against methicillin-resistant Staphylococcus aureus (MRSA). Canadian Journal of Microbiology, v.60, n.10, p.629-638, 2014. https://doi.org/10.1139/cjm-2014-0286

LEITE, M.V.; STAMFORD, T.C.M.; STAMFORD-ARNAUD, T.M.; LIMA, J.M.N.; SILVA, A.M.; OKADA, K.; CAMPOS-TAKAKI, G.M. Conversion of agro-industrial wastes to chitosan production by Syncephalastrum racemosum UCP 1302. International Journal of Applied Research in Natural Products, v.8, n.4, p.5-1 1, 2015.

MAGESH, H.; KUMAR, A.; ALAM, A.; PRIYAM; SEKAR, U; SUMANTRAN, VN; VAIDYANATHAN, R. Identification of natural compounds which inhibit biofilm formation in clinical isolates of Klebsiella pneumoniae. Indian Journal of Experimental Biology, v.51, n.9, p.764-772, 2013.

MOHANASRINIVASAN, V.; MISHRA, M.; PALIWAL, J.S.; SINGH, S.K.; SELVARAJAN, E.; SUGANTHI, V.; DEVI, C.S. Studies on heavy metal removal efficiency and antibacterial activity of chitosan prepared from shrimp shell waste. 3 Biotech, v.4, n.2, p.167175, 2014. https://doi.org/10.1007/s13205-013-0140-6

O'CALLAGHAN, K.A.; KERRY, J.P. Preparation of low-and mediummolecular weight chitosan nanoparticles and their antimicrobial evaluation against a panel of microorganisms, including cheesederived cultures. Food Control, v.69, p.256-261, 2016. https:// doi.org/10.1016/j.foodcont.2016.05.005

PALOMINO, J.C.; MARTIN, A.; CAMACHO, M.; GUERRA, H.; SWINGS, J.; PORTAELS, F. Resazurin microtiter assay plate: simple and inexpensive method for detection of drug resistance in Mycobacterium tuberculosis. Antimicrobial Agents and Chemotherapy, v.46, n.8, p.2720-2722, 2002. https://doi.org/10.1128/ aac.46.8.2720-2722.2002

RAAFAT, D.; VON BARGEN, K.; HAAS, A.; SAHL, H.G. Insights into the mode of action of chitosan as an antibacterial compound. Applied and Environmental Microbiology, v.74, n.12, p.37643773, 2008. https://doi.org/10.1128/AEM.00453-08

SAMAR, M.M.; EL-KALYOUBI, M.H.; KHALAF, M.M.; EL-RAZIK, M.A. Physicochemical, functional, antioxidant and antibacterial properties of chitosan extracted from shrimp wastes by microwave technique. Annals of Agricultural Sciences, v.58, n.1, p.33-41, 2013. https://doi.org/10.1016/j.aoas.2013.01.006

SANTOS, J.E.; SOARES, J.D.P.; DOCKAL, E.R.; CAMPANA FILHO, S.P.; CAVALHEIRO, E.T. Caracterização de quitosanas comerciais de diferentes origens. Polímeros, v.13, n.4, p.242-249, 2003. http://dx.doi.org/10.1590/SO104-14282003000400009

SOUZA, F.M.; FERREIRA, R.M.S.; BARBOSA, R.C. Utilização da casca de camarão para produção de quitina. Revista Scire, v.7, n. 1, p. $1-11,2015$.

VILAR JUNIOR, J.; MAIA, P.S.; SANTOS, V.P.; COSTA FILHO, C.; LIMA, G.S.; NASCIMENTO, A.E.; CAMPOS-TAKAKI, G.M. Microbial and crustacean Chitosan: isolation, characterization and antimicrobial activity. In: MÉNDEZ-VILAS, A. (Ed.). Microbes in the Spotlight: recent progress in the understanding of beneficial and harmful microorganisms. Boca Raton, Florida: BrownWalker Press, 2016. p.290-294.

ZHANG, H.; YUN, S.; SONG, L.; ZHANG, Y.; ZHAO, Y. The preparation and characterization of chitin and chitosan under large-scale submerged fermentation level using shrimp by-products as substrate. International Journal of Biological Macromolecules, v.96, p.334-339, 2017 . https://doi.org/10.1016/j. ijbiomac.2016.12.017 